\title{
Technologia wytwarzania oraz plan kontroli jakości przegrzewacza pary kotła parowego wg PN-EN 12952-5
}

\author{
Workmanship technique and quality control plan for \\ the steam boiler superheater acc. to PN-EN 12952-5
}

\section{Streszczenie}

W artykule przedstawiono historię rozwoju przegrzewaczy pary oraz omówiono ich budowę i zastosowanie. Szczegółowo odniesiono się do wytwarzania oraz kontroli tych urządzeń, omawiając wymagania w zakresie spawania elementów przegrzewaczy pary przedstawione w PN-EN 12952-6. Podano szczegółowy plan spawania oraz plan kontroli jakości stworzony w oparciu o wymagania normy PN-EN 12952-6.

\section{Abstract}

The historical characteristics of steam superheaters were presented in the paper. It was discussed the construction and application of these devices. The issues on workmanship and inspection were presented in detail. The requirements on pre-heater elements welding, presented in PN-EN 12952-6 standard, were shown. The detailed welding plan and quality control plan, done on the basis of PN-EN 12952-6 requirements, were described.

\section{Wstęp}

Definicję komory podano w PN-EN 12952-3, wg której za komorę uważa się część rurową o nominalnej średnicy zewnętrznej większej od 76,2 mm, do której wchodzą nieosiowo trzy lub więcej rury. Komory kotłowe obok walczaka lub wodooddzielacza ( $w$ zależności od konstrukcji kotła) są jednym z najważniejszych elementów ciśnieniowych kotła parowego (rys. 1). Ze względu na obciążenia termiczne oraz obciążenia pochodzące od ciśnienia, elementy te podlegają specjalnemu traktowaniu pod względem zastosowanych materiałów, wytwarzania oraz kontroli podczas procesu produkcji. Szczególne znaczenie ma proces wytwarzania przy zastosowaniu technologii spawania poszczególnych elementów komór kotłowych (króćce, dennice, elementy rurowe).

W artykule przedstawiono wymagania PN-EN 12952-5 Kotly wodnorurowe i urządzenia pomocnicze. Wytwarzanie i budowa części ciśnieniowych kotłów,

Dr hab. inż. Jacek Słania, prof. PCz - Politechnika Częstochowska, mgr inż. Paweł Urbańczyk - Urząd Dozoru Technicznego.

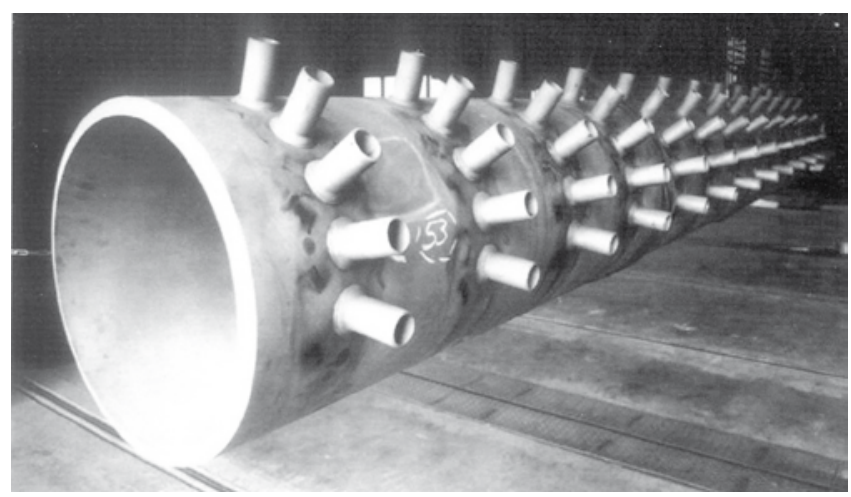

Rys. 1. Komora przegrzewacza pary [2]

Fig. 1. Steam superheater chamber [2]

związane z wytwarzaniem komór kołłów parowych. Omówiono również przykładowy plan kontroli jakości stosowany przy wytwarzaniu komór kotłowych.

\section{Przegrzewacze pary w energetyce}

Przegrzewacz pary jest elementem ciśnieniowym kotła parowego zbudowanego przeważnie z pęczków rur - wężownic - połączonych z kolektorami bądź 
komorami zbiorczymi, wlotową i wylotową. Zadaniem przegrzewacza jest doprowadzenie ciepła do pary nasyconej, suchej wytworzonej w parowniku i otrzymanie pary przegrzanej.

Przegrzewacze pary ze względu na sposób wymiany ciepła można podzielić na: opromieniowane, półopromieniowane i konwekcyjne.

Przy niskich ciśnieniach przegrzewacze umieszcza się w strefie niskiej temperatury spalin (drugi ciąg kotła). Ze wzrostem ciśnienia powierzchnia parownika zmniejsza się, a rośnie powierzchnia przegrzewacza. Przegrzewacz należy wówczas umieścić w strefie możliwie najwyższej temperatury. Duże przegrzewacze dzieli się na dwa lub więcej stopni, aby istniała możliwość montażu pomiędzy nimi regulatorów temperatury pary i mieszania pary, niwelując nierównomierności temperatury po stronie spalin oraz stronie pary. Jest to szczególnie istotne dla kotłów na wysokie parametry pary, gdy materiał wężownic pracuje w wysokiej temperaturze i jest w strefie bliskiej granicy dopuszczalnej wytrzymałości na pełzanie [1].

\section{Przegrzewacze wtórne}

Przegrzewaczami wtórnymi pary wodnej nazwano urządzenia stosowane w celu podniesienia sprawności siłowni parowej. Para po częściowym rozprężeniu w części wysokoprężnej turbiny kierowana jest powtórnie do kotła parowego, w którym następuje podniesienie jej temperatury (a więc i entalpii). Oprócz podniesienia sprawności zabieg ten powoduje zwiększenie stopnia suchości pary na wylocie z turbiny.

\section{Przegrzewacze pary w kotłach bloków energetycznych na parametry nad- i ultranadkrytyczne}

Zastosowanie przegrzewaczy zwiększyło sprawność kotła energetycznego oraz obiegu siłowni parowych. Najnowsze kotły są budowane na parametry nadkrytyczne oraz o jeszcze większej sprawności - jednostki na parametry ultranadkrytyczne (temperatura pary przekracza $620^{\circ} \mathrm{C}$ ). Dla tak wysokich parametrów przewidziano zastosowanie stali ferrytyczno-martenzytycznych ( $p=260$ bar; $t=545^{\circ} \mathrm{C}$ ), austenitycznych ( $p=290$ bar, $t=600^{\circ} \mathrm{C}$ ) oraz dla bloków pracujących na parametry ultranadkrytyczne stopów niklu $\left(p=350\right.$ bar, $\left.t>700^{\circ} \mathrm{C}\right)$ [6].

Przyjęto, że dzięki zwiększeniu parametrów następuje wzrost sprawności ok. $0,5 \%$ na każde $10^{\circ} \mathrm{C}$ przyrostu temperatury pary świeżej i wtórnie przegrzanej oraz ok. $0,2 \%$ na każdy $1 \mathrm{MPa}$ podwyższenia ciśnienia pary świeżej. Efektem zastosowania wyższych parametrów początkowych jest zwiększenie sprawności bloku o $1,3 \div 2,0 \%[6]$.
Praca przy takich parametrach wymaga zastosowania zaawansowanych technologii przy wytwarzaniu materiałów na elementy ciśnieniowe, jak i łączeniu tych materiałów, a w szczególności ich spawania.

Wysoką sprawność bloków energetycznych kocioł - turbina - generator osiąga się na etapie projektowania m.in. przez wzrost temperatury wody zasilającej, oraz próżni w kondensatorze, obniżanie temperatury wylotowej spalin, a zwłaszcza przez wzrost ciśnienia i temperatury pary.

\section{Parametry nadkrytyczne i ultranadkrytyczne - rys historyczny}

Pierwszym zbudowanym na świecie dużym blokiem na ultranadkrytyczne parametry pary $\left(p=345\right.$ bar, $\left.t=649^{\circ} \mathrm{C}\right) \mathrm{z}$ podwójnym przegrzewem wtórnym $\left(566 / 566^{\circ} \mathrm{C}\right)$ o mocy $325 \mathrm{MW}$ był kocioł uruchomiony w USA w 1959 r. w elektrowni Eddystone, należącej do Philadelphia Electric Co. Ze względu na zastosowanie do jego budowy nieodpowiedniej jakości materiałów, dyspozycyjność bloku była bardzo niska. Skutkiem niepowodzeń konstrukcyjnych było wycofanie się z budowania dalszych bloków na ultranadkrytyczne parametry pary (USC). Podjęto jednak budowę bloków na parametry nadkrytyczne (SC). W rezultacie w latach $1960 \div 1990$ w USA zbudowano łącznie 159 bloków o mocy $300 \div 1400 \mathrm{MW}$ na ciśnienia $230 \div 260$ bar i temperaturę $540 \div 590^{\circ} \mathrm{C}$. W tej liczbie 118 bloków węglowych (14 bloków z podwójnym przegrzewem wtórnym), 40 na gaz ziemny oraz tylko 1 na olej opałowy [7].

W Europie najbardziej znaczące osiągnięcia w zakresie budowy bloków na parametry nadkrytyczne odnotować trzeba w Danii i w Niemczech. Istotna jest podjęta w ostatnich latach w Niemczech bu-

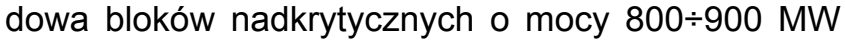
z kotłami opalanymi węglem brunatnym. Na szczególną uwagę zasługuje uruchomiony w 2002 r. w elektrowni Niederaußem blok o mocy 1012 MW brutto (965 MW netto), przy potrzebach własnych $47 \mathrm{MW}$ $(4,65 \%)$, wydajności kotła $2620 \mathrm{t} / \mathrm{h}$, parametrach pary świeżej 274 bar przy $580^{\circ} \mathrm{C}$, pary wtórnie przegrzanej 62 bar $w 600^{\circ} \mathrm{C}$, temperaturze spalin wylotowych $100^{\circ} \mathrm{C}$, sprawności kotła $94,4 \%$ oraz sprawności całego bloku przekraczającej $43 \%$ (netto). Wszystkie kolektory, z wyjątkiem kolektora wylotowego, wykonane są ze stali P91, a ostatnie stopnie przegrzewacza pierwotnego oraz przegrzewacz międzystopniowy ze stali austenitycznej X3CrNiMoN17-13 (17\% chromu oraz $12 \%$ niklu). Po raz pierwszy do konstrukcji kolektora wylotowego wykorzystany został materiał E 911 (X11CrMoWVNb9-1-1), będący stopem wolframu i chromu $z$ dodatkiem niobu. Umożliwiło to wykonanie kolektora wylotowego $\left(274 \mathrm{bar} / 580^{\circ} \mathrm{C}\right)$ o grubości ścianki $75 \mathrm{~mm}$, podczas gdy grubość tej ścianki wykonanej ze stali P 91 musiała by wynosić $100 \mathrm{~mm}$. Budowę bloku rozpoczęto w sierpniu 1998 r., a zakończono w grudniu 2002 r. [7]. 


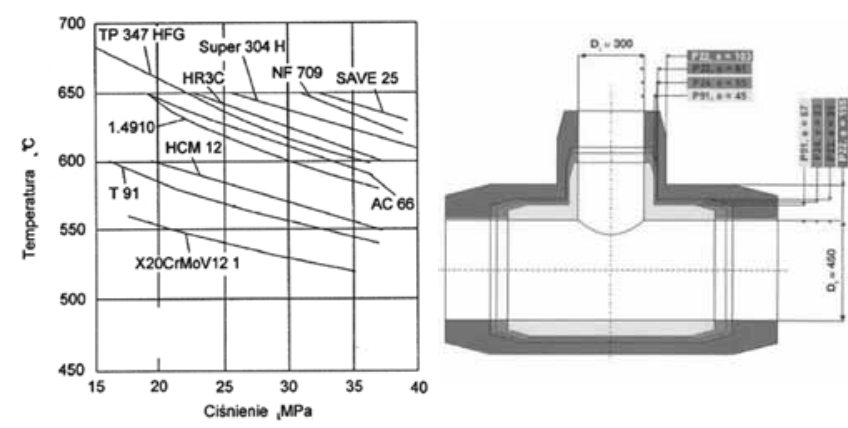

Rys. 2. Wpływ parametrów pracy na dobór materiałów przeznaczonych na wytwarzanie elementów ciśnieniowych w kotłach energetycznych [2, 3]

Fig. 2. Influence of running parameters on the choice of materials assigned for pressure elements in power boilers manufacturing $[2,3]$

W Polsce ostatnio oddanym do eksploatacji blokiem na parametry nadkrytyczne jest blok 858 MW w PGE Górnictwo i Energetyka Konwencjonalna S.A. Elektrownia Bełchatów. Wpływ parametrów pracy na dobór materiałów przeznaczonych na wytwarzanie elementów ciśnieniowych w kotłach energetycznych przedstawiono na rysunku 2.

Podstawowymi konstrukcjami kotłów używanych do generacji pary o parametrach nadkrytycznych są kotły przepływowe, których elementy ciśnieniowe wykonywane są ze stali żarowytrzymałych, ferrytyczno-martenzytycznych oraz austenitycznych. Układ przepływowy kotła na parametry nadkrytyczne wymaga pompy wody zasilającej o dużej wysokości podnoszenia, napędzanej turbiną, która musi wytworzyć wysokie ciśnienie statyczne czynnika, pozwalające pokonać duże opory przepływu spowodowane gęstością i większą prędkością czynnika oraz mniejszymi średnicami wewnętrznymi rur. Kocioł składa się z typowych podzespołów charakterystycznych dla kotła konwencjonalnego, tj. podgrzewacza wody, parownika, przegrzewaczy pary pierwotnej i wtórnej oraz rurociągów komunikacyjnych. Elementem występującym w kotłach na parametry nadkrytyczne jest wodooddzielacz niezbędny w pracy przy niższych wartościach obciążenia kotła.

Przy zastosowaniu nadkrytycznych parametrów pary w warunkach spalania możliwe jest już uzyskanie sprawności cieplnej ponad 45\%, w porównaniu z maksymalna $41 \%$ sprawnościa konwencjonalnych elektrowni cieplnych [6]. Uzyskanie wyższych sprawności bloków energetycznych może być osiągalne przez rozwój technologii opartej na opanowaniu parametrów ultranadkrytycznych. Na świecie prowadzone są badania w ramach dużych projektów międzynarodowych (program THERMIE 700 Advanced Power Plant dofinansowany przez UE) mające umożliwić osiąganie temperatury pary ok. $700^{\circ} \mathrm{C}$ i ciśnienia 37,5 MPa [6]. W tym celu wprowadzane są np. nowe stale żarowytrzymałe o podwyższonych właściwościach użytkowych, a na elementy krytyczne (przegrzewacze pary, rurociągi komunikacyjne) wysokostopowe stale martenzytyczne i austenitycznych oraz stopy niklu. Zastosowanie materiałów w zależności od temperatury pracy elementu ciśnieniowego kotła przedstawiono na rysunku 3.
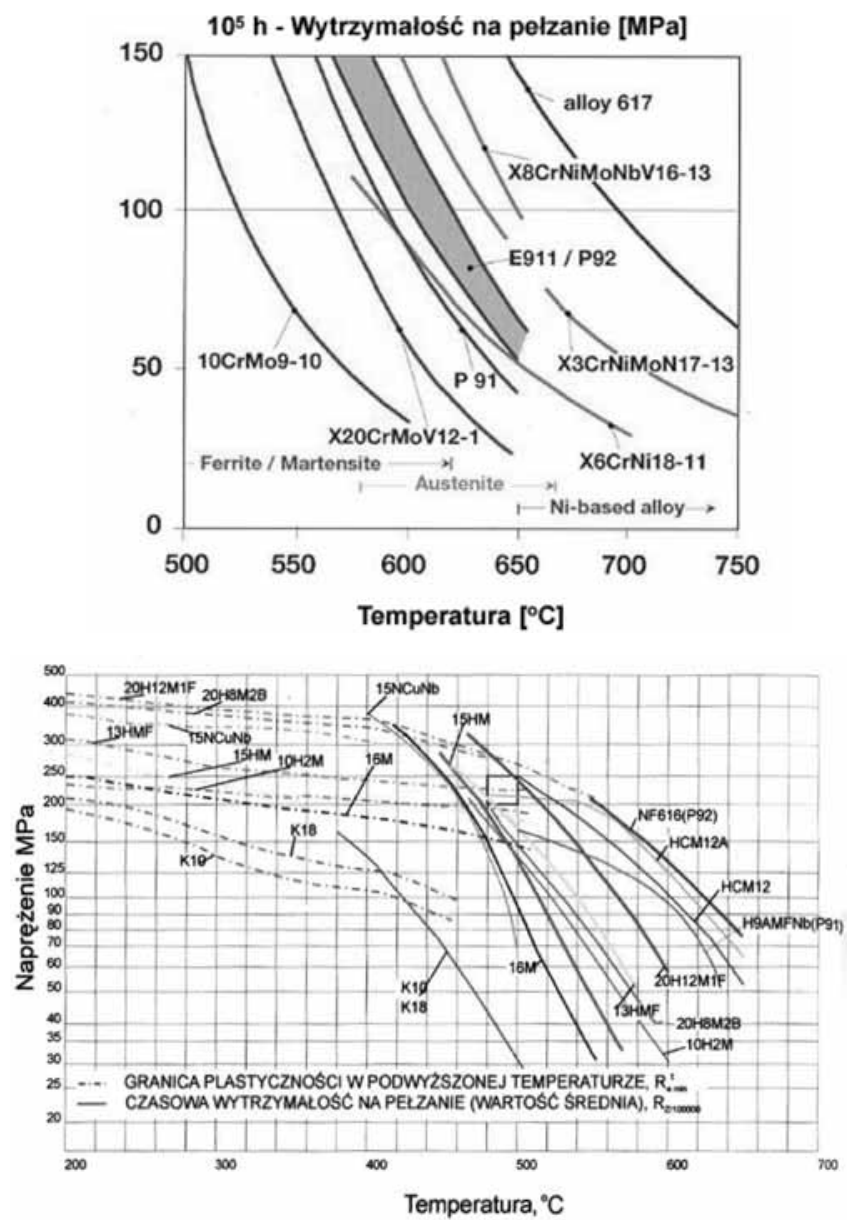

Rys. 3. Zastosowanie materiałów w zależności od temperatury pracy elementu ciśnieniowego kotła $[2,6]$

Fig. 3. Application of different materials, depending on the work temperature of the pressure element of the boiler $[2,6]$

\section{Wytwarzanie i badania elementów przegrzewaczy pary}

Z przykładów wynika, że najbardziej obciążonym, a zarazem jednym z najistotniejszych elementów kotła jest przegrzewacz pary, który ze względu na warunki pracy (ciśnienie i temperatura) oraz stosowane rozwiązania materiałowo-technologiczne wymaga od projektantów i wytwórców wysokich kwalifikacji i specjalistycznej wiedzy.

Podczas wytwarzania elementów ciśnieniowych przegrzewaczy pary stosowana jest przez wytwórców norma PN-EN 12952-5 Kotły wodnorurowe i urządzenia pomocnicze. Wytwarzanie i budowa części ciśnieniowych kotłów.

Jest ona normą zharmonizowaną z dyrektywą dotyczącą urządzeń ciśnieniowych 97/23/WE, zgodnie z którą wszystkie kotły energetyczne jako urządzenia ciśnieniowe powinny przechodzić ocenę zgodności. Zastosowanie normy zharmonizowanej w pełnym zakresie dowodzi zgodności z zasadniczymi wymaganiami bezpieczeństwa określonymi w dyrektywie. W PN-EN 12952-5 określono wymagania dotyczące wytwarzania i budowy kotłów wodnorurowych 
zdefiniowanych w PN-EN 12952-1 Kotty wodnorurowe i urządzenia pomocnicze. Postanowienia ogólne.

Podczas projektowania, wytwarzania i badania elementów przegrzewaczy pary można ograniczyć się do stosowania podstawowych części normy, a mianowicie:

- PN-EN 12952-1 Kotły wodnorurowe i urządzenia pomocnicze. Postanowienia ogólne,

- PN-EN 12952-2 Kotły wodnorurowe i urządzenia pomocnicze. Materiały na części ciśnieniowe kotłów i wyposażenie,

- PN-EN 12952-3 Kotły wodnorurowe i urządzenia pomocnicze. Konstrukcja i obliczenia części ciśnieniowych,

- PN-EN 12952-5 Kotły wodnorurowe i urządzenia pomocnicze. Wytwarzanie i budowa części ciśnieniowych kotłów,

- PN-EN 12952-6 Kotły wodnorurowe i urządzenia pomocnicze. Badania podczas wytwarzania; sporządzanie dokumentacji i znakowanie części ciśnieniowych kotłów.

Istotnym elementem jest technologia wytwarzania oraz kontrola procesów produkcyjnych na każdym etapie produkcyjnym oraz dotrzymanie reżimów wytwarzania, dla których np. ogólne wytyczne spawania stali ferrytycznych, które mogą być stosowane w celu uzupełnienia wymagań dotyczących spawania w zakresie PN-EN 12952-5, podano w PN-EN 1011-1 i PN-EN 1011-2.

\section{Wymagania PN-EN 12952-5}

\section{Wytwórca}

Wytwórca kotła powinien dostarczyć na żądanie rysunki wykonawcze z wszystkimi wymiarami, ilustrujące budowę wszystkich części ciśnieniowych poddawanych spawaniu i kopie stosowanych instrukcji technologicznych spawania przygotowane zgodnie z PN-EN 12952-6, rozdz. 6. Rysunki z wymiarami głównych części ciśnieniowych powinny zawierać lokalizację wszystkich elementów i ich położenie względem złączy wzdłużnych głównych złączy i zamocowań części, ilustrując szczegóły przygotowania złącza spawanego głównego, wszystkich złączy spawanych i obwodowych oraz otworów.

Spawanie połączeń części zespołów kotłów wodnorurowych należy podjąć tylko wtedy, kiedy spełnione są następujące warunki:

- instrukcje technologiczne spawania powinny być zestawione przez wytwórcę zgodnie z PN-EN ISO 15609-1 dla każdego połączenia lub każdej grupy połączeń,

- instrukcje technologiczne spawania wybrane przez wytwórce powinny być kwalifikowane dla obszaru zastosowań,

- spawacze i operatorzy urządzeń spawalniczych powinni mieć kwalifikacje do wykonywania prac im przydzielonych i posiadać ważne uprawnienia.
Tablica I. Odległości pomiędzy rozgałęzieniami i głównymi złączami spawanymi [4]

Table I. Distance between branchings and main welded joints [4]

\begin{tabular}{|c|c|}
\hline Grubość walczaka lub komory (e), mm & Odległość $(\Delta), \mathrm{mm}$ \\
\hline $\mathrm{e} \leq 25$ & $\Delta>2 \times \mathrm{e}$ \\
\hline $\mathrm{e}>25$ & $\Delta>50$ \\
\hline
\end{tabular}

Nie dopuszcza się stosowania złączy spawanych doczołowych na łukach rur, z wyjątkiem specjalnych przypadków kotłów ze spiralnymi powierzchniami grzewczymi.

Brzeg spoin łączących umocowania z głównymi częściami ciśnieniowymi nie powinien być zlokalizowany bliżej niż $40 \mathrm{~mm}$ od głównych złączy spawanych. Jeśli ten warunek nie występuje, to spoina umocowania powinna się krzyżować całkowicie z głównym złączem spawanym. W takich przypadkach powierzchnia głównego złącza spawanego i spoin umocowania powinna być miejscowo zeszlifowana po kompletnym spawaniu umocowania. Część złączy spawanych mocujących, które krzyżują się z głównymi złączami spawanymi, należy traktować jako „przenoszące obciążenie" ze względu na stosowane badania nieniszczące. Takie badania nieniszczące powinny być przeprowadzane zgodnie $z$ wymaganiami podanymi w PN-EN 12952-6.

Zaleca się, aby otwory pod rozgałęzienia, jeśli występują, były oddalone od głównych złączy spawanych walczaków i komór. Odległość taką uważa się za odpowiednią, jeżeli odległość między krawędzią głównego złącza spawanego a krawędzią rozgałęzienia lub nałożonego wzmocnienia spełnia wszystkie wymagania podane $w$ tablicy I.

Jeżeli, ze względu na konstrukcję, nie można zapewnić takich odległości, złącza spawane należy poddać badaniom nieniszczącym w obszarach wpływu otworów i przeszlifować do gładkiej powierzchni w celu usunięcia wszystkich karbów w tym obszarze.

Jeżeli wymagane jest lokalne przeszlifowanie złączy spawanych, powierzchnia przeszlifowania powinna w 100\% zostać poddana badaniu nieniszczącemu, zgodnie z wymaganiami podanymi w PN-EN 12952-6, rozdz. 9.

Niedopuszczalna jest obróbka mechaniczna otworów w doczołowych złączach spawanych wzdłużnych, dopuszczalne są natomiast otwory obrabiane mechanicznie w środku doczołowych złączy spawanych obwodowych, jeżeli zostaną poddane badaniu nieniszczącemu zgodnie z PN-EN 12952-6, rozdz. 9 na całej długości obrabianego mechanicznie obszaru.

Należy unikać spawania w miejscu budowy materiałów znacznie różniących się, np. stali austenitycznej ze stalą ferrytyczną.

\section{Materiały dodatkowe do spawania}

Elektrody, druty spawalnicze, pręty spawalnicze, topniki, wkładki topnikowe, gazy osłonowe i oczyszczające 
powinny być zgodne z odpowiednimi normami europejskimi lub normami krajowymi, gdy brak odnośnych norm europejskich.

Wytwórca kotła powinien zapewnić, że odpowiednie materiały dodatkowe, wymienione $w$ instrukcji technologii spawania, będą zastosowane w procesach wytwórczych.

Wszystkie materiały dodatkowe wraz z gazami powinny być przechowywane i wykorzystywane w należyty sposób, zgodnie z warunkami określonymi przez producenta tych materiałów.

\section{Kwalifikowanie technologii spawania}

Kwalifikowanie technologii spawania powinno być zgodne z EN ISO 15614-1 lub EN ISO 15613-1 (wg PN-EN 12952-6, rozdz. 6).

Technologie spawania przy wykonywaniu złączy doczołowych rur z materiałów kompozytowych związanych metalurgicznie powinny być zgodne z wymaganiami podanymi w PN-EN ISO 15613-1. Ponadto należy uwzględnić specjalne wymagania wytwórcy rur. Technologie należy kwalifikować, stosując rury z materiałów kompozytowych, zgodnych z taką samą specyfikacją jak dla rur stosowanych do budowy kotła.

\section{Egzaminowanie i szkolenie spawaczy}

Egzaminowanie spawaczy i operatorów urządzeń spawalniczych powinno być przeprowadzane zgodnie z PN-EN 287-1 i PN-EN 1418. Za szkolenie, nadzór i kontrolę spawaczy oraz operatorów urządzeń spawalniczych powinien być odpowiedzialny wytwórca.

\section{Stan powierzchni przed spawaniem}

Rowki do spawania i materiał graniczący na powierzchniach zewnętrznych i wewnętrznych powinny być suche i oczyszczone z tłuszczu, oleju, środków smarnych, znaków naniesionych lakierem, zendry lub innych zanieczyszczeń, aż do czystej metalicznie powierzchni, na takiej odległości od krawędzi spawanych, która pozwoli zapobiec wnikaniu zanieczyszczeń do złącza. Wymiary szczeliny w grani są wymiarami po sczepianiu. Należy ograniczyć do minimum liczbę części tymczasowo przyspawanych do części ciśnieniowych.

Części przyspawane tymczasowo (z wyjątkiem urządzenia do próby ciśnieniowej) należy usunąć przed pierwszym wytworzeniem ciśnienia w kotle, jeżeli nie zostały zaprojektowane $z$ uwzględnieniem takich samych wymagań jak przyspawane części stałe.

Należy usunąć wszystkie części zamocowane tymczasowo. Obszar po usunięciu należy lekko przeszlifować, a przed wyżarzaniem odprężającym sprawdzić występowanie niezgodności powierzchniowych, stosując odpowiednią metodę kontrolną, właściwą dla zastosowanego materiału. W czasie wykonywania spoin sczepnych i spawania klamer lub innych części mocowanych należy stosować i utrzymywać odpowiednie warunki nagrzewania.

Materiał dodatkowy do wykonywania spoin sczepnych powinien odpowiadać przeznaczeniu danego złącza i być nałożony w czasie spawania zgodnie z uznanymi instrukcjami technologicznymi spawania. Szczególną uwagę należy poświęcić jakości spoin sczepnych, które powinny być wykonane przez spawaczy z wymaganymi uprawnieniami. W razie konieczności końce spoin sczepnych, jeżeli będą położone w grani, należy przygotować przez szlifowanie lub struganie w celu uzyskania dobrego przetopu. Wszystkie pęknięte spoiny sczepne należy całkowicie usunąć.

\section{Naprawa złączy spawanych}

Jeżeli zachodzi konieczność wykonania naprawy złącza spawanego, należy posługiwać się uznanymi technologiami spawania i wykorzystywać spawaczy z uprawnieniami odpowiednimi do zakresu wykonywanej pracy. Rodzaj i zakres takich napraw powinien stanowić część kompletu dokumentacji wytwórcy. Jeżeli radiogramy lub inne protokoły badań nieniszczących poddaje się kontroli, wytwórca powinien udostępnić wszystkie poprzednie protokoły dotyczące obszarów naprawianych.

Szczegóły napraw złączy spawanych należy udostępnić personelowi wykonującemu badania nieniszczące, odpowiedzialnemu za powtórzenie badania. W przypadkach częściowego usunięcia złączy spawanych, wycinana część materiału powinna być odpowiednio głęboka i długa, aby usunąć całą niezgodność. Na końcach kraterów należy wykonać łagodny skos od dna do powierzchni metalu spawanego.

Jeżeli całość złącza spawanego jest usuwana i ponownie wykonuje się spoiny czołowe, należy wykonać nową płytę próbną, jeżeli jest to wymagane w PN-EN 12952-6. Jeżeli naprawiane są złącza doczołowe, części i płyty próbne (jeśli są) należy poddać obróbce cieplnej zgodnie z odpowiednimi rozdziałami przywołanej normy europejskiej, a płyty próbne badać zgodnie z PN-EN 12952-6.

Wszystkie naprawiane obszary połączeń ponownie spawanych należy poddać badaniu nieniszczącemu zgodnie z PN-EN 12952-6, rozdz. 9 i poddać takim samym badaniom i kontroli jak połączenia oryginalne.

Wytwórca powinien przechowywać protokoły, w których zaznaczono: położenie, długość, szerokość i głębokość wszystkich wykonanych napraw: doczołowych złączy wzdłużnych i obwodowych komór oraz doczołowych złączy w rurach jednolitych o grubości powyżej 25 mm lub o średnicy zewnętrznej powyżej 170 mm.

Naprawy wykonywane na innych złączach spawanych należy zapisać w odpowiednim protokole badań 
Tablica II. Zalecane wartości temperatury nagrzania wstępnego dla cięcia termicznego [4]

Table II. Recommended temperatures of pre-heating for thermal cutting [4]

\begin{tabular}{|c|c|c|c|}
\hline Rodzaj stali & $\begin{array}{c}\text { Grupa } \\
\text { stali }\end{array}$ & $\begin{array}{c}\text { Grubość } \\
\mathrm{mm}\end{array}$ & $\begin{array}{c}\text { Minimalna temperatura na- } \\
\text { grzewania wstępnego, }{ }^{\circ} \mathrm{C}\end{array}$ \\
\hline $\begin{array}{c}\text { Węglowa } \\
\text { C-Mn }\end{array}$ & 1 & $\begin{array}{c}\leq 150 \\
>150\end{array}$ & $\begin{array}{c}\text { niewymagane } \\
50\end{array}$ \\
\hline 0,3 Mo & 1 & $\begin{array}{c}<30 \\
\geq 30\end{array}$ & $\begin{array}{c}\text { niewymagane } \\
100\end{array}$ \\
\hline Różna & 2.1 i 4 & $\begin{array}{c}<15 \\
\geq 15\end{array}$ & $\begin{array}{c}\text { niewymagane } \\
150\end{array}$ \\
\hline 1 Cr 1/2 Mo & 5.1 & $\begin{array}{c}<50 \\
\geq 50\end{array}$ & $\begin{array}{c}\text { niewymagane } \\
150\end{array}$ \\
\hline $21 / 4$ Cr 1 Mo & 5.2 & $\begin{array}{c}<50 \\
\geq 50\end{array}$ & $\begin{array}{c}100 \\
150\end{array}$ \\
\hline 9 Cr 1Mo & 6 & wszystkie & 150 \\
\hline 12 Cr 1Mo V & 6 & wszystkie & 200 \\
\hline $\begin{array}{l}\text { UWAGA: Podane zalecenia maja charakter ogólnych wytycznych } \\
\text { do stosowania w praktyce. Inna temperatura nagrzewania wstęp- } \\
\text { nego jest dopuszczalna. }\end{array}$
\end{tabular}

nieniszczących. Zalecane wartości temperatury nagrzania wstępnego dla cięcia termicznego przedstawiono w tablicy II.

\section{Obróbka cieplna po spawaniu}

Badając po obróbce cieplnej materiał części zaprojektowanych do pracy z granicą plastyczności w podwyższonej temperaturze, dopuszcza się dla materiału podstawowego, w indywidualnych przypadkach, zmniejszenie o $5 \%$ podanej w specyfikacji wartości minimalnej granicy plastyczności i wartości wytrzymałości na rozciąganie. Dopuszcza się wartości mniejsze, w granicach 5 i $10 \%$, niż podana w specyfikacji minimalna granica plastyczności i wartość wytrzymałości na rozciąganie, jeżeli można wykazać, że:

- obróbka cieplna została wykonana prawidłowo;

- wymagania dotyczące wydłużenia dla materiału podstawowego przy rozciąganiu zostały spełnione;

- wymagania odnośnie udarności dla materiału podstawowego zostały spełnione;

- grubość ścianki części jest właściwa dla konstrukcji z uzyskanymi wartościami granicy plastyczności.

Dla części zaprojektowanych do pracy w zakresie pełzania dopuszcza się wartości mniejsze niż podana w specyfikacji minimalna wartość granicy plastyczności i minimalna wartość wytrzymałości na rozciąganie maksymalnie do $10 \%$. Zakresy wartości temperatury obróbki cieplnej po spawaniu oraz czas utrzymania temperatury w procedurach obróbki cieplnej złączy spawanych podano w tablicach III i IV.

Tablica III. Zakresy wartości temperatury obróbki cieplnej po spawaniu, złącza spawane z materiałów podobnych i materiałów różnych [4] Table III. Range of temperature of heat treatment after welding, joints welded from similar and dissimilar materials [4]

\begin{tabular}{|c|c|c|c|c|c|c|c|c|c|c|}
\hline \multirow{2}{*}{ Rodzaj stali } & \multirow{2}{*}{$\begin{array}{l}\text { Grupa } \\
\text { stali }\end{array}$} & \multicolumn{9}{|c|}{ Zakres temperatury, ${ }^{\circ} \mathrm{C}$} \\
\hline & & 1 & 1 & 2.1 & 2.1 & $4^{a}$ & 5.1 & 5.2 & $6^{\mathrm{b}}$ & $6^{b}$ \\
\hline C-Mn & 1 & $550-600$ & $550-600$ & $550-600$ & $550-600$ & & & & & \\
\hline 0,3 Mo & 1 & $550-600$ & $550-630$ & $550-600$ & $550-600$ & & $600-630$ & & & \\
\hline Drobnoziarnista & 2.1 & $550-600$ & $550-600$ & $550-600$ & $570-600$ & & & & & \\
\hline \multirow[t]{2}{*}{$1 \mathrm{NiMoCuNb}$} & 2.1 & $550-600$ & $550-600$ & $570-600$ & $570-620$ & & $600-620$ & & & \\
\hline & $4^{a}$ & & & & & & & & & \\
\hline $1 \mathrm{Cr} 1 / 2 \mathrm{Mo}$ & 5.1 & & $600-630$ & & $600-620$ & & $620-680$ & $660-700$ & & \\
\hline $21 / 4 \mathrm{Cr} 1 \mathrm{Mo}$ & 5.2 & & & & & & $660-700$ & $680-730$ & $\begin{array}{l}730-760 \\
710-730^{c}\end{array}$ & $\begin{array}{l}730-760 \\
710-730^{\circ}\end{array}$ \\
\hline $9 \mathrm{Cr} 1 \mathrm{Mo}$ & $6^{b}$ & & & & & & & $\begin{array}{l}710-730^{\circ} \\
730-760\end{array}$ & $740-780$ & $740-770$ \\
\hline $12 \mathrm{Cr} 1 \mathrm{MoV}$ & $6^{b}$ & & & & & & & $\begin{array}{l}730-760 \\
710-730^{\circ} \\
\end{array}$ & $740-770$ & $730-770$ \\
\hline \multicolumn{11}{|c|}{$\begin{array}{l}\text { a Określa się na podstawie norm materiałowych i kart materiałowych. } \\
\text { b Materiały te wymagają przemiany martenzytycznej przed obróbką cieplną po spawaniu. } \\
\text { c Tylko dla materiałów dodatkowych w rodzaju } 21 / 4 \mathrm{Cr} 1 \mathrm{Mo} \text {. } \\
\text { UWAGA } 1 \text { Inne kombinacje materiałów, niepodane w powyższej tablicy, i odstępstwa od temperatur podanych w tablicy można dopuścić, } \\
\text { pod warunkiem że wytwórca może zapewnić, że ich stosowanie nie obniży bezpieczeństwa kotła w eksploatacji. } \\
\text { UWAGA } 2 \text { Temperatura obróbki cieplnej po spawaniu dla złączy ferrytycznych i austenitycznych pomiędzy różnymi materiałami powinna } \\
\text { być taka, jaka jest wymagana dla strony ferrytycznej złącza. }\end{array}$} \\
\hline
\end{tabular}


Tablica IV. Czas utrzymania temperatury w procedurach obróbki cieplnej złączy spawanych [4]

Table IV. Time of temperature maintenance for welded joints heat treatment procedures [4]

\begin{tabular}{|c|c|c|c|c|c|c|c|}
\hline \multirow[b]{2}{*}{$\begin{array}{l}\text { Rodzaj typowej } \\
\text { stali }\end{array}$} & \multirow[b]{2}{*}{ Grupa stali } & \multicolumn{2}{|c|}{ Strefa I } & \multicolumn{2}{|c|}{ Strefa II } & \multicolumn{2}{|c|}{ Strefa III } \\
\hline & & \begin{tabular}{c|}
$\begin{array}{c}\text { Minimalna } \\
\text { okeślona } \\
\text { grubość } \\
\text { złącza e } \\
\mathrm{mm}\end{array}$ \\
\end{tabular} & $\begin{array}{l}\text { Minimalny czas } \\
\text { wytrzymania } t_{1} \\
\text { min. }\end{array}$ & $\begin{array}{c}\text { Minimalna okeślona } \\
\text { grubość złącza e } \\
\text { mm }\end{array}$ & $\begin{array}{l}\text { Minimalny czas } \\
\text { wytrzymania } t_{2} \\
\text { min. }\end{array}$ & $\begin{array}{c}\text { Minimalna } \\
\text { określona } \\
\text { grubość złącza e } \\
\text { mm }\end{array}$ & $\begin{array}{l}\text { Minimalny czas } \\
\text { wytrzymania } t_{3} \\
\text { min. }\end{array}$ \\
\hline C-Mn & 1 & $\mathrm{e}<35$ & $\begin{array}{c}\text { OC nie } \\
\text { wymagana }\end{array}$ & $35 \leq$ e $\leq 90$ & $t_{2}=1 \times e$ & $e>90$ & $t_{3}=90+0,5 \times(e-90)$ \\
\hline $0,3 \mathrm{Mo}$ & 1 & $e<35$ & $\begin{array}{c}\text { OC nie } \\
\text { wymagana }\end{array}$ & $35 \leq \mathrm{e} \leq 90$ & $t_{2}=1 \times e$ & $e>90$ & $t_{3}=90+1 \times(e-90)$ \\
\hline Drobnoziarnista & 2.1 & e $<35$ & $\begin{array}{c}\text { OC nie } \\
\text { wymagana }\end{array}$ & $35 \leq \mathrm{e} \leq 60$ & $t_{2}=2 \times e$ & $e>60$ & $\mathrm{t}_{3}=120+0,5 \times(e-60)$ \\
\hline \multirow[t]{2}{*}{$1 \mathrm{NiMoCuNb}$} & 2.1 & $\mathrm{e}<13$ & $t_{1}>13$ & $13 \leq e \leq 60$ & $\mathrm{t}_{2}=1 \times \mathrm{e}$ & $e>60$ & $\mathrm{t}_{3}=60+0,5 \times(e-60)$ \\
\hline & $4^{a}$ & & & & & & \\
\hline $1 \mathrm{Cr} 1 / 2 \mathrm{Mo}$ & 5.1 & $e<13 b$ & $t_{1}>30$ & $13 \leq e \leq 60$ & $t_{2}=2 \times e$ & $e>60$ & $t_{3}=120+1 \times(e-60)$ \\
\hline $21 / 4 \mathrm{Cr} 1 \mathrm{Mo}$ & 5.2 & $\mathrm{e}<13$ 。 & $t_{1}>30$ & $13 \leq \mathrm{e} \leq 60$ & $t_{2}=2 \times e$ & $e>60$ & $t_{3}=120+1 \times(e-60)$ \\
\hline $9 \mathrm{Cr} 1 \mathrm{Mo}$ & 6 & $e<13$ & $t_{1}>30$ & $35 \leq \mathrm{e} \leq 90$ & $\mathrm{t}_{2}=2,5 \times \mathrm{e}$ & e $>90$ & $t_{3}=225+1 \times(e-90)$ \\
\hline $12 \mathrm{Cr} 1 \mathrm{MoV}$ & 6 & $e<13$ & $t_{1}>30$ & $35 \leq \mathrm{e} \leq 90$ & $t_{2}=2,5 \times e$ & e $>90$ & $\mathrm{t}_{3}=225+0,5 \times(e-90)$ \\
\hline \multicolumn{3}{|c|}{ 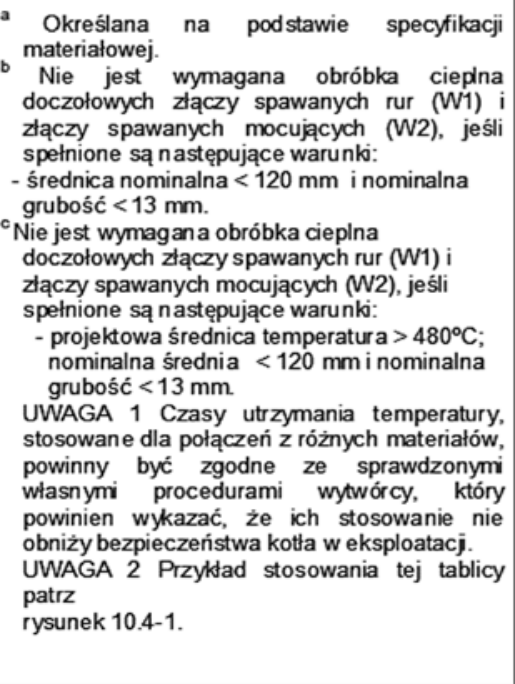 } & \multicolumn{5}{|c|}{$\begin{array}{l}\text { Objaśnienia } \\
\text { a Minimalny czas utrzymania temperatury } t \\
\text { b Minimalna grubość reprezentatywna } \\
\text { złącza e } \\
\text { c Patrz kolumna } 4 \\
\text { d t }_{2}=(1 \ldots 2,5) \times e(\text { patrzkolumna } 6) \\
\text { e } t_{3}=t_{2}+(0,5 \ldots 1)(e-e 2) \text { patrz } \\
\text { kolumna } 8 \\
\text { f Strefa I } \\
\text { g Strefa II } \\
\text { h Strefa III }\end{array}$} \\
\hline
\end{tabular}

\section{Spawanie po końcowejobróbce cieplnej}

Specjalne przypadki mogą się pojawić, gdy zachodzi konieczność spawania części ciśnieniowych po zakończeniu obróbki cieplnej, np. spawanie oddzielnych mocowanych małych części i wykonanie pojedynczych małych napraw. Takie podejście należy dopuścić dla stali grup 1.1, 1.2, 5.1 i 5.2 zgodnie z CR ISO 15608, pod warunkiem że spawanie odpowiada uznanej instrukcji technologicznych spawania, zgodnej z wymaganiami PN-EN ISO 15614-1 z uwzględnieniem następujących wymagań:

- Minimalne podgrzanie wstępne powinno być zgodne $z$ tablicą II. Dla stali $z$ grupy 5.1 i 5.2 temperatura podgrzania powinna być $\geq 200^{\circ} \mathrm{C}$.

- Należy stosować elektrody o kontrolowanej zawartości wodoru, suszone przynajmniej wg wymagań PN-EN 1011-2, skala D lub, alternatywnie, proces zapewniający uzyskanie podobnego poziomu zawartości wodoru, np. spawanie metodą TIG.
- Tam gdzie jest to możliwe, materiał spoiny należy nakładać przynajmniej w dwóch warstwach, z minimalną ilością przerwań i rozpoczęć spawania. Dla stali chromowo-molibdenowych Cr-Mo należy nakładać co najmniej dwie warstwy materiału.

- Grubość złączy spawanych mocujących części nieciśnieniowe nie powinna przekraczać $13 \mathrm{~mm}$.

- Dla stali chromowo-molibdenowej Cr-Mo wymiary średnicy zewnętrznej króćców nie powinny przekraczać $57 \mathrm{~mm}$, a grubość $10 \mathrm{~mm}$.

- Metal spoiny powinien w sposób łagodny przechodzić w materiał podstawowy części i jeśli jest to wymagane, powinien być obrobiony mechanicznie.

- Po zakończeniu wszystkich spawań i niezbędnej obróbki mechanicznej, gdy jest to konieczne, złącza spawane należy zbadać metodą magnetyczno-proszkową. 


\section{Połączenia spawane, przyłączenia i płyty próbne}

\section{Doczołowe złącza spawane wzdłużne i obwodowe oraz płyty próbne w komorach}

Jeżeli stosuje się spawanie wielościegowe, każdy ścieg przed ułożeniem następnego powinien być czysty i wolny od żużla, z wyjątkiem gdy instrukcja technologiczna spawania dopuszcza co innego. Nie należy stosować trwałych podkładek pierścieniowych w doczołowych złączach spawanych komór.

Wkładek ulegających stopieniu nie uważa się za podkładki pierścieniowe. Wkładki ulegające stopieniu należy stosować tylko wtedy, gdy materiał, z którego są wykonane, jest porównywalny z materiałem podstawowym i gdy ulegną one całkowitemu stopieniu w wykonywanym połączeniu.

Jeżeli stosowane jest doczołowe złącze spawane z blachami o różnej grubości, grubość grubszej blachy należy zmniejszyć. Grubsza blacha powinna mieć płynne ścięcie, włączając $w$ to szerokość złącza, jeżeli jest konieczne. Wymagane ścięcie należy wykonać, nanosząc dodatkowy materiał spoiny poza szerokością, która w innym przypadku będzie krawędzią złącza. Jeżeli wymagane jest badanie metodą ultradźwiękową, to - stosując odpowiednie środki - należy zapewnić możliwość pełnego skanowania głowicą.

\section{Spawanie rozgałęzień, króćców, końcówek i innych części do walczaka i komór}

W każdym złączu spawanym należy układać spoinę przynajmniej dwoma ściegami. Każdy ścieg przed ułożeniem następnego powinien być czysty i wolny od żużla.

\section{Spawanie rozgałęzień, króćców, końcówek i innych części do komór}

Przy spawaniu nie należy stosować trwałych wkładek pierścieniowych. Wkładów ulegających stopieniu nie uważa się za podkładki pierścieniowe. Wkłady ulegające stopieniu należy stosować tylko wtedy, kiedy materiał, z którego są wykonane, jest porównywalny z materiałem podstawowym i kiedy ulegną one całkowitemu stopieniu w wykonywanym połączeniu.

Jeżeli przewiduje się stosowanie złączy spawanych o częściowym przetopie, należy podać na rysunku głębokość przetopu.
Powierzchnia gotowego złącza powinna być wolna od niezgodności pomiędzy poszczególnymi warstwami, a ostateczne wykończenie wszystkich złączy spawanych powinno być takie, żeby zmiana przekroju między poszczególnymi częściami była płynna i wolna od ostrych karbów i znaczących podcięć.

Złącza spawane, łączące rozgałęzienia, króćce i końcówki z komorami, nie powinny być połączeniami stali austenitycznych ze stalami ferrytyczny$\mathrm{mi}$, chociaż dopuszczalne są takie połączenia dla króćców małych przyrządów pomiarowych wykonanych ze stali austenitycznej. W rurach kompozytowych należy usunąc warstwę kompozytową, przygotowując krawędź złącza przed spawaniem z walczakiem lub komorą. Jest niedopuszczalne stopienie jakiejkolwiek stali austenitycznej w jeziorku złącza spawanego podczas spawania części wykonanej ze stali węglowej.

\section{Nakładki, blachy wzmacniające}

Z wyjątkiem przypadku, gdy podano wymiary charakterystyczne na rysunku, maksymalny odstęp między stroną zewnętrzną każdego rozgałęzienia lub powłoki a wewnętrzną krawędzią otworu w powłoce, kołnierzem, pierścieniem wzmacniającym lub podkładką pierścieniową nie powinien przekraczać $1,5 \mathrm{~mm}$ dla otworów do $300 \mathrm{~mm}$ i $3 \mathrm{~mm}$ dla otworów powyżej $300 \mathrm{~mm}$. Chcąc uzyskać taki odstęp - zewnętrzną średnicę powłoki lub króćca można obrobić maszynowo na wystarczającej długości, aby zapewnić zamocowanie, do którego ma być przyspawana.

\section{Zamocowanie przez spawanie części nieciśnieniowych do komór}

Dopuszczalne jest mocowanie przez spawanie części nieciśnieniowych (np. wsporniki, ucha transportowe, podpory, płaskowniki) do komór.

Złącza spawane mocujące, przeznaczone do przenoszenia obciążeń, powinny być złączami ciągłymi. Takie złącza spawane powinny być na pełnym obwodzie zamocowania i mogą one być dwustronne o częściowym przetopie lub jednostronne o pełnym przetopie, albo dwustronne o pełnym przetopie.

Wybrane połączenie należy poddać badaniu nieniszczącemu, zgodnie z PN-EN 12952-6, rozdz. 6.

Dopuszczalne jest wykonanie złączy spawanych mocujących nieprzenoszących obciążeń za pomocą przerywanych spoin pachwinowych. Gdy stosuje się złącza spawane wielościegowe, po każdym ułożeniu ściegu spoiny należy oczyścić powierzchnię do czystego metalu przed ułożeniem kolejnego ściegu. Podgrzewanie wstępne i obróbkę cieplną po spawaniu należy przeprowadzać według tablic II i III. 


\section{Spawanie rur - ciągłość spawania}

Bez względu na rodzaj stali, ściegi graniowe należy nakładać w sposób ciągły, jeżeli nie jest to spowodowane zmianą elektrody lub materiału dodatkowego, lub zmianą pozycji spawacza. Złączy spawanych wymagających podgrzania wstępnego i wykonywanych na budowie nie wolno poddawać schładzaniu, dopóki długość wykonanej spoiny nie przekroczy jednej trzeciej jej pełnej grubości. Przy spawaniu innych stali niż stale węglowe lub stale węglowo-manganowe w razie wystąpienia przerw w spawaniu, których trudno uniknąć, należy utrzymywać temperaturę podgrzewania wstępnego. Jeżeli jest to niemożliwe, należy owinąć połączenie spawane suchym kocem termoizolującym w celu zapewnienia powolnego schładzania. Przed rozpoczęciem kolejnego spawania należy powtórzyć nagrzanie wstępne.

W miarę możliwości zaleca się unikanie przerw w spawaniu.

Ściegi graniowe spoin położone w warsztacie można schłodzić tylko wówczas, gdy uwzględni się środki zapewniające powolne schłodzenie, np. owinięcie suchym kocem termoizolującym.

\section{Zakończenie spawania}

Aby zmniejszyć ryzyko związane z powstaniem pęknięć zimnych, wywołanych obecnością wodoru, szczególnie w przypadku stali wysokostopowych $\mathrm{Cr}$ Mo, złącze spawane należy zawinąć suchym kocem termoizolacyjnym, aby zapewnić powolne schłodzenie. Nie jest to wymagane, gdy przeprowadzi się natychmiast obróbkę cieplną lub utrzyma się temperaturę podgrzewania wstępnego.

\section{Odległość pomiędzy spoinami czołowymi}

Dla rur o średnicy do $250 \mathrm{~mm}$ włącznie odległość między spoinami czołowymi nie powinna być mniejsza niż wartość równa podwójnej średnicy zewnętrznej. Dla rur o średnicy zewnętrznej powyżej $250 \mathrm{~mm}$ odległość nie powinna być mniejsza niż $500 \mathrm{~mm}$.

\section{Przesunięcie otworów w rurach}

Zaleca się, aby średnice wewnętrzne sąsiednich końców rur możliwie dokładnie pasowały do siebie. Dopuszczalne różnice średnicy wewnętrznej i przesunięcia otworów podano $w$ tablicy $\mathrm{V}$.

Spawanie złączy rurowych według wymagań omawianej normy powinno uwzględnić, jeżeli to konieczne, dopasowanie przez wytwórcę końców rury w każdym połączeniu. $\mathrm{Na}$ dopasowanie otworów
Tablica V. Tolerancje przesunięcia otworów w rurach [4] Table V. Tolerances of displacement for holes in pipes [4]

\begin{tabular}{|c|c|c|}
\hline $\begin{array}{c}\text { Średnica } \\
\text { otworu rury } \\
\mathrm{mm}\end{array}$ & $\begin{array}{c}\text { Maksymalna różnica } \\
\text { średnic wewnętrznych } \\
\mathrm{mm}\end{array}$ & $\begin{array}{c}\text { Maksymalne przesunięcie linii } \\
\text { środkowej rur sasiednich } \\
\mathrm{mm}\end{array}$ \\
\hline do 80 & 1,0 & 1,0 \\
\hline 80 do 300 & 1,5 & 1,5 \\
\hline ponad 300 & 2,0 & 2,0 \\
\hline
\end{tabular}

wewnętrznych rur może mieć wpływ dobór, ustawianie za pomocą trzpienia (na gorąco lub zimno), obróbka mechaniczna, kucie profilowe lub odpowiednie rozwalcowanie. Żadne wymagane pogłębianie maszynowe otworu nie może powodować zmniejszenia grubości ścianki rury poniżej grubości obliczeniowej. Wszystkie końce rur ustawiane za pomocą trzpienia na gorąco powinny być obrobione cieplnie, zgodnie z wymaganiami odnośnych norm materiałowych lub odpowiednich arkuszy danych materiałowych.

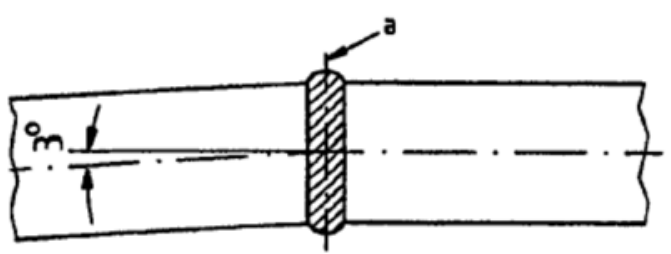

Rys. 4. Przesunięcie kątowe linii środkowej rur spawanych doczołowo, a - linia środkowa złącza spawanego [4]

Fig. 4. Angle shift of centre line of butt welded pipes, a - centre line of welded joint [4]

\section{Przesunięcie kątowe rur spawanych doczołowo}

Przesunięcie kątowe linii środkowej rur spawanych doczołowo zwykle nie powinno przekraczać $3^{\circ}$, tzn. $5 \mathrm{~mm}$ na $100 \mathrm{~mm}$ długości, ale w każdym przypadku powinno być zgodne z odpowiednimi wymaganiami konstrukcyjnymi (rys. 4).

\section{Kuki złożone z części}

Niedopuszczalne są łuki segmentowe i łuki wykonane za pomocą wycinania i spawania.

\section{Podkładki pierścieniowe}

Zastosowanie trwałych podkładek pierścieniowych jest niedopuszczalne dla rur parownika. Można stosować tymczasowe podkładki pierścieniowe ze stali lub materiałów niemetalowych, które są obojętne lub nie mają wpływu na materiał podstawowy. Po zakończeniu spawania powinny zostać usunięte. 


\section{Usunięcie gazów z obszaru złączy spawanych}

Jeżeli w instrukcji technologicznej spawania podano, że wymagane jest usunięcie powietrza $z$ obszaru grani, należy powietrze usunąć z obszaru złącza, przepuszczając wystarczająca ilość gazu czyszczącego, aby zapobiec utlenieniu ściegu graniowego. Powietrze należy usuwać, przepuszczając gaz czyszczący na całej długości rury lub za pomocą miejscowego oczyszczenia, stosując przejściowe zapory. Takie zapory wytwórca powinien usunąć po zakończeniu spawania.

\section{Spawanie rozgałęzień, króćców i końcówek do rur}

Każda spoina powinna być wykonana $z$ nałożeniem przynajmniej dwóch ściegów. Każdy ścieg powinien być oczyszczony i wolny od żużla przed nałożeniem kolejnego ściegu. Niedopuszczalne jest stosowanie trwałych podkładek pierścieniowych. Wkładki ulegające stopieniu są dopuszczalne tylko wtedy, kiedy materiał, z którego są wykonane, jest zgodny z materiałem podstawowym i jeśli ulega on całkowitemu stopieniu w połączeniu spawanym.

Powierzchnia zewnętrzna gotowego złącza powinna być wolna od niezgodności pomiędzy poszczególnymi warstwami spoiny, a ostateczne wykończenie wszystkich złączy powinno być takie, żeby zmiana przekroju pomiędzy częściami była płynna i wolna od ostrych karbów i podcięć, w zakresie dopuszczalnym, określonym w PN-EN 12952-6. Podgrzewanie wstępne, tam gdzie to konieczne, powinno być przeprowadzane zgodnie $z$ tablicą 2 tej normy.

Złącza spawane, łączące rozgałęzienia, króćce i końcówki z rurami nie powinny zawierać połączeń stali austenitycznych i stali ferrytycznych.

\section{Zamocowanie przez spawanie części nieciśnieniowych do rur}

Złącza spawane przeznaczone do przenoszenia obciążeń powinny być ciągłe. Złącze powinno być złączem ze spoinami pachwinowymi wzdłuż obwodu zamocowania, złączem z częściowym przetopem, złączem jednostronnym z pełnym przetopem lub złączem dwustronnym z pełnym przetopem. Połączenie powinno być poddane badaniu nieniszczącemu, w sposób podany w PN-EN 12952-6, rozdz. 9.

Dopuszczalne jest wykonanie złączy spawanych zamocowań nieprzenoszących obciążeń w postaci złączy pachwinowych przerywanych.
Jeśli stosuje się spawanie wymagające nałożenia wielu warstw w spoinie, każdą warstwę metalu należy oczyścić do czystego metalu przed nałożeniem kolejnej warstwy. Podgrzewanie i obróbka cieplna po spawaniu powinny być stosowane, gdy są wymagane według tablic 2 i 3 w PN-EN 12952-6, rozdz. 9.

\section{Zgrzewanie doczołowe rur}

Zgrzewanie doczołowe rur powinno być zgodne $z$ wymaganiami odpowiedniej normy europejskiej. W razie braku takiej normy dopuszczalne jest stosowanie norm krajowych lub uznawanych norm międzynarodowych dotyczących iskrowego zgrzewania doczołowego rur.

\section{Czynności kontrolne wytwórcy}

Lista czynności kontrolnych wykonywanych przez wytwórcę kotła wodnorurowego lub jego elementów ciśnieniowych jest podzielona ze względu na zakres działalności oraz prowadzone badania (tabl. VI). Dotyczy: projektu i dokumentacji, materiałów zastosowanych przy produkcji, wytwarzania i spawania, badań nieniszczących złączy spawanych, obróbki cieplnej po spawaniu, badań końcowych i znakowania.

Lista ta powinna zostać zaimplementowana przez wytwórcę do systemu kontroli elementów ciśnieniowych kotła, jakimi są przegrzewacze pary.

Dodatkowo zamieszczony jest przykładowy plan kontroli i badań stworzony na podstawie przedstawionej listy czynności kontrolnych, która stanowi spełnienie wymagań normy PN-EN 12952-6 (tabl. VII).

Zamieszczony plan kontroli jakości obejmuje wszystkie operacje technologiczne mogące wystąpić $\mathrm{w}$ procesie wytwarzania przegrzewaczy pary, poza próbą ciśnieniową, która z reguły dla takich elementów wykonywana jest po zblokowaniu dla całego kotła parowego na miejscu jego docelowej eksploatacji.

Wytwórca elementów kotłowych powinien potwierdzić, że są one zgodne co najmniej z wymaganiami normy, wykonując odpowiednie czynności podane w tablicy VI.

W zależności od przyjętego modułu oceny zgodności niektóre z czynności kontrolnych powinny być ocenione przez właściwą jednostkę notyfikowaną (wg PN-EN 12952-17). 
Tablica VI. Lista czynności kontrolnych wykonywanych przez wytwórcę (wg PN-EN 12952-6) [7]

Table VI. List of inspection activities done by the manufacturer (acc. to PN-EN 12952-6) [7]

\begin{tabular}{|c|c|}
\hline Zakres działalności & Przeprowadzone badanie \\
\hline \multicolumn{2}{|c|}{ 1. PROJEKT I OGÓLNA DOKUMENTACJA } \\
\hline 1.1 Dane projektowe/obliczenia & $\begin{array}{l}\text { Sprawdzenie, czy dane projektowe/obliczenia są zgodne: } \\
\text { - ze specyfikacjami technicznymi, jeśli są stosowane } \\
\text { - z wymaganiami odpowiedniej normy europejskiej }\end{array}$ \\
\hline 1.2 Rysunki wykonawcze & $\begin{array}{l}\text { Sprawdzenie, czy dane na rysunkach są zgodne: } \\
\text { - z danymi projektowymi i obliczeniami } \\
\text { - ze specyfikacjami technicznymi, jeśli są stosowane } \\
\text { - z wymaganiami odpowiedniej normy europejskiej }\end{array}$ \\
\hline 1.3 Specyfikacja zakupu & $\begin{array}{l}\text { Sprawdzenie, czy specyfikacje dla materiałów i części są zgodne: } \\
\text { - ze specyfikacjami technicznymi, jeśli są stosowane } \\
\text { - z rysunkami wykonawczymi } \\
\text { - z wymaganiami odpowiedniej normy europejskiej }\end{array}$ \\
\hline 1.4 Specyfikacja części poddostawców & $\begin{array}{l}\text { Sprawdzenie, czy specyfikacja dotycząca części podzlecanych jest zgodna: } \\
\text { - ze specyfikacjami technicznymi, jeśli są stosowane } \\
\text { - z rysunkami wykonawczymi } \\
\text { - z wymaganiami odpowiedniej normy europejskiej }\end{array}$ \\
\hline \multicolumn{2}{|r|}{ 2. MATERIAt } \\
\hline 2.1 Świadectwa materiałowe & Sprawdzenie, czy informacja w świadectwie i wyniki są zgodne ze specyfikacją projektową \\
\hline 2.2 Materiały dodatkowe do spawania & $\begin{array}{l}\text { Sprawdzenie, czy stosowane materiały dodatkowe do spawania są zgodne ze specyfika- } \\
\text { cją projektową }\end{array}$ \\
\hline 2.3 Oznaczenie materiału & Sprawdzenie zgodności materiału ze świadectwem materiałowym i sprawdzenie oznakowania \\
\hline 2.4 Przenoszenie znaków identyfikacyjnych & Sprawdzenie, czy przenoszenie znaków identyfikacyjnych jest zgodne z uznaną procedurą \\
\hline 2.5 Odbiór części podzleconych & Sprawdzenie, czy części podzlecone są zgodne ze specyfikacją wytwórcy \\
\hline \multicolumn{2}{|r|}{ 3. WYTWARZANIE I SPAWANIE } \\
\hline 3.1 Instrukcje technologii spawania & $\begin{array}{l}\text { Sprawdzenie, czy istnieją odpowiednie instrukcje spawania i czy ich zakres jest zgodny } \\
\text { z kwalifikowaną technologią spawania }\end{array}$ \\
\hline 3.2 Kwalifikowanie technologii spawania & $\begin{array}{l}\text { Sprawdzenie, czy technologie spawania są odpowiednie dla materiałów i obszaru zastoso- } \\
\text { wania spawania, i czy były kwalifikowane przez odpowiednie jednostki }\end{array}$ \\
\hline 3.3 Uprawnienia spawaczy & $\begin{array}{l}\text { Sprawdzenie, czy uprawnienia spawaczy zostały udzielone przez upoważnione jednostki } \\
\text { i czy uprawnienia są aktualne i ważne }\end{array}$ \\
\hline 3.4 Technologie obróbki plastycznej & $\begin{array}{l}\text { Sprawdzenie, czy są dostępne technologie obróbki plastycznej, jeżeli są stosowane, } \\
\text { i czy ich zakres jest odpowiedni dla wykonywanego wyrobu }\end{array}$ \\
\hline 3.5 Przygotowanie do spawania & $\begin{array}{l}\text { Kontrola stanu krawędzi materiału tam gdzie stosowano cięcie palnikiem i potwierdzenie, } \\
\text { że kształt przygotowanych mechanicznie krawędzi jest poprawny }\end{array}$ \\
\hline 3.6 Części obrabiane plastycznie & Kontrola części obrabianych plastycznie zgodnie z wymaganiami wg EN 12952-5, rozdz. 7 \\
\hline 3.7 Złącze spawane w stanie sczepienia & Sprawdzenie złącza spawanego w stanie sczepienia wraz z kontrolą wymiarów \\
\hline 3.8 Grań spoiny & $\begin{array}{l}\text { Sprawdzenie przeciwległej strony przygotowywanego złącza, jeśli to ma miejsce, po wyko- } \\
\text { naniu spawania pierwszej strony i oczyszczeniu grani }\end{array}$ \\
\hline \multirow{5}{*}{ 3.9 Płyty próbne, jeśli są stosowane } & Identyfikacja i oznakowanie płyt próbnych \\
\hline & $\begin{array}{l}\text { Sprawdzenie, czy obróbka cieplna po spawaniu na płycie próbnej, niezależnie od rodzaju } \\
\text { części, odpowiada właściwej obróbce cieplnej stosowanej do tej części }\end{array}$ \\
\hline & Kontrola wyników badań nieniszczących płyt próbnych \\
\hline & Identyfikacja i znakowanie próbek do badań właściwości mechanicznych pobranych z płyt próbnych \\
\hline & $\begin{array}{l}\text { Sprawdzenie, czy informacje z badań właściwości mechanicznych są zgodne z wymaga- } \\
\text { niami odpowiedniej normy europejskiej }\end{array}$ \\
\hline \multicolumn{2}{|r|}{ 4. BADANIA NIENISZCZĄCE ZŁĄCZY SPAWANYCH } \\
\hline 4.1 Procedury badań nieniszczących & $\begin{array}{l}\text { Sprawdzenie, czy dane projektowe/obliczenia są zgodne ze specyfikacjami technicznymi, } \\
\text { jeśli ma to zastosowanie - z wymaganiami odpowiedniej normy europejskiej }\end{array}$ \\
\hline $\begin{array}{l}\text { 4.2 Kwalifikacje wykonawców badań } \\
\text { nieniszczących }\end{array}$ & $\begin{array}{l}\text { Sprawdzenie, czy dane zawarte na rysunku są zgodne: } \\
\text { - z danymi projektowymi i obliczeniami } \\
\text { - ze specyfikacjami technicznymi, jeśli ma to zastosowanie - z wymaganiami } \\
\text { odpowiedniej normy europejskiej }\end{array}$ \\
\hline 4.3 Wykonywanie badań nieniszczących & Analiza naświetlonych radiogramów i sprawdzenie z kryteriami odbiorowymi \\
\hline 4.4 Raporty z badań nieniszczących & Sprawdzenie, czy zamieszczone informacje i wyniki są zgodne z kryteriami odbioru \\
\hline \multicolumn{2}{|r|}{ 5. OBRÓBKA CIEPLNA PO SPAWANIU } \\
\hline 5.1 Procedury obróbki cieplnej po spawaniu & $\begin{array}{l}\text { Sprawdzenie, czy procedury obróbki cieplnej po spawaniu są zgodne z niniejszą normą } \\
\text { europejska }\end{array}$ \\
\hline 5.2 Wykresy z obróbki cieplnej po spawaniu & $\begin{array}{l}\text { Sprawdzenie, czy zarejestrowane temperatury/czasy są zgodne z wymaganiami odpowied- } \\
\text { niej normy europejskiej }\end{array}$ \\
\hline \multicolumn{2}{|r|}{ 6. BADANIE KOŃCOWE I ZNAKOWANIE } \\
\hline 6.1 Badanie poprzedzające próbę ciśnieniową & $\begin{array}{l}\text { Przeprowadzenie kontroli wymiarowej, badania wizualne i identyfikacja dostępnych części } \\
\text { po zakończeniu montażu, a przed rozpoczęciem próby ciśnieniowej }\end{array}$ \\
\hline 6.2 Próba ciśnieniowa & $\begin{array}{l}\text { Sprawdzenie, czy końcowa próba ciśnieniowa jest wykonywana zgodnie z warunkami } \\
\text { podanymi w odpowiedniej normie europeiskiej }\end{array}$ \\
\hline 6.3 Badanie po zakończeniu próby ciśnieniowej & Badanie wizualne po zakończeniu próby ciśnieniowej \\
\hline 6.4 Urządzenia zabezpieczające & Sprawdzenie wyposażenia w urządzenia zabezpieczające \\
\hline 6.5 Dokumentacja wytwórcy & Sprawdzenie dokumentacji wytwórcy pod względem kompletności \\
\hline
\end{tabular}


Tablica VII. Plan kontroli jakości opracowany na postawie wymagań normy PN-EN 12952-6

Table VII. Quality control plan done on the basis of PL-EN 12952-6 requirements

PLAN KONTROLI JAKOŚCI

\section{Nazwa części:}

Komora przegrzewacza pary I stopnia

Nr rys. zestawieniowego

\begin{tabular}{|l|l|}
\hline $\mathrm{Nr}$ & Opis operacji/ Zakres kontroli
\end{tabular}

Nr pozycji rys.

\section{1. $\quad$ Dane projektowe i obliczenia}

2. $\quad$ Rysunki warsztatowe/montażowe

3. Zestawienia materiałowe

4. Specyfikacje dla elementów podzlecanych

\begin{tabular}{l|l}
\hline 5. & Dokumenty kontroli materiałów podstawowych
\end{tabular}

6. $\quad$ Materiały dodatkowe do spawania

7. Oznaczenia materiałów podstawowych

8. $\quad$ Przeniesienie oznaczeń materiałowych

9. Akceptacja elementów podzlecanych

10. $\quad$ Instrukcje Technologiczne Spawania

11. Zatwierdzenie Instrukcji Technologicznych Spawania

12. Uprawnienia spawaczy

13. Procedury kształtowania/gięcia

14. Elementy po przeróbce plastycznej

15. $\quad$ Pomiary grubości ścianek rur giętych

16. Obliczenia owalizacji

17. Kontrola kulowania

18. $\quad$ Kontrola obróbki cieplnej po gięciu

19. $\quad$ Sprawdzenie wyników z badania twardości po gięciu

20. $\quad$ Trasowanie głównych wymiarów komór

21. Ustawienie szwu spawalniczego

22. Grań spoiny

23. $\quad$ Próby produkcyjne (jeśli wymagane)

24. $\quad$ Proces spawania (wyrywkowo)

25. $\quad$ Proces naprawczy (jeśli jest wymagany)

26. $\quad$ Procedury badań nieniszczących

27. Kwalifikacje personelu badań NDT

28. Operacje badań NDT

29. $\quad$ Raporty z badań NDT

30. $\quad$ Kontrola spoin (po badaniach NDT)

31. $\quad$ Procedury obróbki cieplnej po spawaniu

32. $\quad$ Raporty z obróbki cieplnej po spawaniu

33. Pomiar twardości po obróbce cieplnej po spawaniu

KONTROLA KOŃCOWA WYROBU I ZNAKOWANIE

Sprawdzenie wymiarów, kontrola wizualna i identyfikacja

34. części elementów po jego kompletacji, kontrola czystości wewnętrznej i zewnętrznej

35. Spoiny po malowaniu

36. Pakowanie elementów

37. $\quad$ Kompletacja dokumentacji powykonawczej

38. Znakowanie zgodnie z odpowiednimi przepisami

$39 . \quad$ Deklaracja wytwórcy

BADANIA NIENISZCZACE

Kontrola/Akceptacja

Gat. materiału

Wymiary materiału podstawowego

Operację wykonał (podpis) Uwagi BP/W/JN

BP

$\mathrm{KJ} / \mathrm{JN}$

O WYTWARZANIA

$\mathrm{KJ} / \mathrm{KW} / \mathrm{JN}$

$\mathrm{KJ} / \mathrm{GS} / \mathrm{JN}$

$\mathrm{KJ} / \mathrm{JN}$

$\mathrm{KJ}$

SKJ

PROCES WYTWARZANIA I SPAWANIE

GS

GS/JN

$\mathrm{KJ} / \mathrm{SKJ}$

$\mathrm{KJ} / \mathrm{SKJ} / \mathrm{JN}$

NDT

$\mathrm{KJ}$

$\mathrm{KW} / \mathrm{KJ} / \mathrm{JN}$

$\mathrm{KJ} / \mathrm{JN}$

SKJ/JN

PW/KJ

PW/GS

$\mathrm{KW} / \mathrm{KJ} / \mathrm{GS}$

$\mathrm{GS} / \mathrm{KJ}$

S/SKJ/JN

SKJ

$\mathrm{KJ} / \mathrm{JN}$

$\mathrm{KJ}$

$\mathrm{KJ} / \mathrm{SKJ} / \mathrm{JN}$

$\mathrm{KJ} / \mathrm{JN}$

GS/SKJ/JN

$\mathrm{KJ} / \mathrm{JN}$

NDT

\begin{tabular}{|c|l|l|}
\hline $\mathrm{KW} / \mathrm{KJ} / \mathrm{JN}$ & & \\
$\mathrm{KJ}$ & & \\
\hline $\mathrm{KW}$ & & \\
$\mathrm{KJ}$ & & \\
$\mathrm{KJ} / \mathrm{JN}$ & & \\
$\mathrm{W}$ & & \\
\hline
\end{tabular}

Skróty: JN - Przedstawiciel Jednostki Notyfikowanej, KL - Klient, KW - Kierownik wytwarzania, W - Wytwórca, NDT - Badania nieniszczące, KJ - Kontrola Jakości, SKJ - Specjalista ds. Jakości, KW - Kontrola wyrywkowa, PW - Pracownik wytwarzania, BP - Biuro projektów, GS - Główny Spawalnik 


\section{Podsumowanie}

W związku ze wzrostem wymagań stawianych wytwórcom energii elektrycznej w zakresie ograniczenia emisji zanieczyszczeń, a w szczególności gazów cieplarnianych, np. dwutlenku węgla, powstała potrzeba wprowadzania technologii umożliwiających ograniczenie emisji tego gazu.

Jednym z podstawowych i najprostszych sposobów realizacji takich założeń jest zwiększanie sprawności siłowni parowych przez podnoszenie parametrów pracy, tj. ciśnienia i temperatury pary wytwarzanej w kotłach parowych, co wiąże się z zastosowaniem technologii związanych $\mathrm{z}$ wykorzystywaniem parametrów nadkrytycznych i ultranadkrytycznych pary. Wymaga to od wytwórców kotłów stosowania nowych materiałów oraz technologii, również związanych ze spawaniem.

Przedstawiono wymagania dotyczące wytwarzania komór kotłowych w oparciu o PN-EN 12952-5, która jest stosowana nie tylko do elementów ciśnieniowych, ale również złożonych zespołów urządzeń ciśnieniowych, jakimi są kotły parowe pracujące w energetyce zawodowej.

Przedstawiono również przykładową listę czynności kontrolnych wykonywanych przez wytwórcę w procesie wytwarzania stworzoną na podstawie PN-EN 12952-6, która może zostać wykorzystana w procesie produkcyjnym.

\section{Literatura}

[1] Orłowski P., Dobrzyński W., Szwarc E.: Kotły parowe. Konstrukcja i obliczenia. WNT, Warszawa 1979.

[2] Materiały reklamowe firmy Boler Schweisstechnik Deutschland $\mathrm{GmbH}$.

[3] Kruczek S.: Kotły. Konstrukcje i obliczenia. Oficyna Wydawnicza Politechniki Wrocławskiej, Wrocław 2001.

[4] PN-EN 12952-5 Kotły wodnorurowe i urządzenia pomocnicze. Wytwarzanie i budowa części ciśnieniowych kotłów.

[5] PN-EN 12952-6 Kotły wodnorurowe i urzadzenia pomocnicze. Badania podczas wytwarzania; sporządzanie dokumentacji i znakowanie części ciśnieniowych kotłów.
[6] Hernas A., Dobrzyński J.: Trwałość i niszczenie elementów kotłów i turbin parowych. Wydawnictwo Politechniki Śląskiej, Gliwice 2003.

[7] Golec T., Rakowski J., Świrski J.: Perspektywy postępu technicznego w wytwarzaniu energii elektrycznej przy wykorzystaniu węgla kamiennego, węgla brunatnego oraz gazu ziemnego z uwzględnieniem efektu środowiskowego. Instytut Energetyki, Warszawa 2003.

\section{Przychód i dochód Kemppi nadal rośnie}

\section{Wydarzenia}

Przychód i zysk operacyjny (EBIT) fińskiego producenta sprzętu spawalniczego Kemppi Oy wzrósł w 2011 r. odpowiednio do $110 \mathrm{mln}$ Euro (+15\%) i do $21 \mathrm{mln}$ Euro $(+23 \%)$. Pomimo kryzysu odnotowano znaczny wzrost popytu na rynkach skandynawskim i europejskim, a najwyższy na rynkach rozwijających się. Firma ustawicznie inwestuje w poszukiwania i rozwój technologii oprogramowania i usług przemysłowych $w$ celu zaoferowania jeszcze szerszego zakresu rozwiązań. W przyszłości coraz większy udział $w$ przychodach ma pochodzić $z$ rynków rozwijających się.

Plany na rok 2012 r. obejmują wprowadzenie na rynek kilku nowych produktów i usług, pomimo niepewnej sytuacji ekonomicznej, co powinno znaleźć odzwierciedlenie we wzroście zarówno przychodu, jak i dochodu. Jedną z najważniejszych premier 2012 r. jest bez wątpienia Kempact RA przeznaczony do podstawowego spawania MIG/MAG. Wcześniej urządzenie zostało nagrodzone znaną na całym świecie nagrodą if Industrial Design Award w kategorii wzornictwa przemysłowego. Poczynając od tego roku, Kemppi będzie produkowało jedynie urządzenia oparte na technologii inwertorowej.

W 1977 r. Kemppi jako pierwsze wprowadziło na rynek wieloprocesową spawarkę inwertorową.

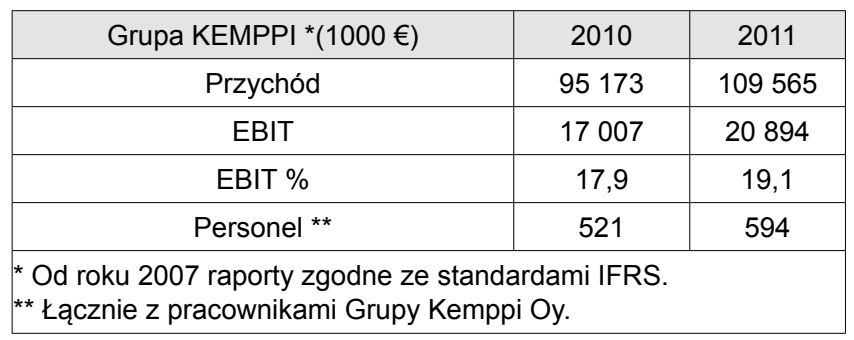

\section{Grupa Kemppi - fakty i liczby:}

- wiodący producentem sprzętu do spawania łukowego oraz dostawca rozwiązań zwiększających wydajność spawania.

- globalne dochody firmy - 110 milionów Euro rocznie.

- fabryki: dwie w Finlandii-Lahti (siedziba główna), Asikkala, oraz jedna w Chennai (Indie).

- Biura w 15 krajach oraz regularny eksport do 70 krajów.

- 600 pracowników, z czego 150 zatrudnionych poza Finlandią.

- Kemppi Oy jest spółką zależną Kemppi Capital Oy. 